\title{
離乳期ラットの肝蔵りソソームアリルスルファターゼ活性 に及ぼす低含硫アミノ酸飼料の影響
}

\author{
木下干 鶴*, 広井祐 三*, 岡 達 三**
名 取 靖 朗**, 谷口 巳佐子* \\ * 中村学園大学食物栄盖学科栄養生化学教室 \\ ** 徳島大学医学部栄養学科栄養化学講座
}

\author{
Effect of a Low-Sulphur-Containing Diet on Lysosomal Arylsulfatase \\ Activity in Weanling Rats \\ Chizuru KINOSHITA,* Yuzo HIROI,* Tatsuzo OKA,** \\ Yasuo NATORI** and Misako TANIGUCHI* \\ * Department of Nutritional Chemistry, School of Food and Nutrition, \\ Nakamura Gakuen College, Fukuoka 814-01 \\ ** Department of Nutritional Chemistry, School of Medicine, \\ the University of Tokushima, Tokushima 770
}

\begin{abstract}
Nippon Eiyō Shokuryō Gakkaishi (J. Jpn. Soc. Nutr. Food Sci.) 46, 401 407 (1993)
The effect of a low-sulphur-containing diet on the hepatic level of lysosomal arylsulfatase activity was studied in weanling rats. Weanling rats fed on a $10 \%$ soybean-protein-isolate diet, which has a low sulphur amino acid content (cystine and methionine, $1.3 \mathrm{~g}$ and $1.4 \mathrm{~g} / \mathrm{kg}$ diet, respectively) about $75 \%$ that of a $10 \%$ casein diet, showed 2.0 -fold increased hepatic lysosomal arylsulfatase activity (total combined activities of arylsulfatases $A$ and B) at 3 weeks and 2.8-fold at 5 weeks, compared with those of rats maintained on an ordinary laboratory chow diet. Weanling rats fed on the casein diet showed a 1.6-fold increased in the total combined activities of arylsulfatases A and B at 5 weeks, compared with those of rats fed on the laboratory chow diet. These increases were suppressed by addition of cystine or methionine to the soybean-protein-isolate diet. On the other hand, liver lysosomal arylamidase activities were not altered significantly by either diet. Therefore, the elevated lysosomal arylsulfatase activities in liver of rats fed on the soybean-protein-isolate diet might be attributable to insufficiency of sulphur-containing amino acids in the diet. The elevation of arylsulfatase activities was not due to changes in arylsulfatase-specific mRNA, as revealed by Northern blot and slot-blot hybridization analysis, since the changes in mRNA content were only marginal. We conclude that induction of lysosomal arylsulfatase activity by a soybean-protein-isolate diet is brought about by an increase in the amount of translation of arylsulfatase mRNA.
\end{abstract}

Key Words soybean protein isolate, arylsulfatase, rat, sulphur metabolism.

(Received January 22, 1993)

分離大豆タンパク質 (soybean protein isolate, SPI) は高コレステロール血症者の血墏コレステロールの低下 作用や正常域者の血墏コレステロールの LDL/HDL 比 の改善作用 ${ }^{122)}$, さらに中性脂肪の低下作用 ${ }^{324)}$ なと脂質 代謝の改善作用を示すことから近年注目されているタン パク質である。

* ₹814-01 福岡市城南区別府 5-7-1

** 千770 徳島市蔵本町 3-18-15
SPI は含硫了ミノ酸のメチオニン含量が低いため, SPI を $10 \%$ 含む低タンハクク質飼料で飼育した幼若ラッ トではシステインの眝葴庫といわれる肝メタロチオネイ ンや肝グルタチオンのレペルが低下し5)6)，その代謝に 関わる ケーグルタミルトランスフェラーゼ (GGT) 活性が 上昇することが見いたされている5)。このことは低含硫 アミノ酸飼料により細胞内の硫酸塩の供与体が減少し, 硫酸塩代謝に関わる酵素の活性が代償的に上昇している 
Table 1. Composition of the soybean protein isolate and casein diet.

\begin{tabular}{lc}
\hline Ingredient & $(\mathrm{g} / \mathrm{kg})$ \\
\hline Soybean protein isolate or Casein & 100 \\
Dextrin & 768.5 \\
Cellulose powder & 20 \\
Mineral mixture & 50 \\
Vitamin mixture & 10 \\
Choline chloride & 1.5 \\
Mize oil & 50 \\
\hline \hline
\end{tabular}

\section{ことを示している。}

本研究は 10，。 SPI を含む低タンパク質飼料で離乳直 後のラットを数週間飼育すると，肝䁍のリソソームに局 在し硫酸塩代謝に関わるアリルスルファターゼ活性が上 昇することを見いだしたので，そのメカニズムについて 検討を行ったものである。

\section{実 験 方 法}

\section{1. 試菜}

分離大豆タンパク質 (SPI) は不二製油俐よりの恵与に よる。固形飼料 (CE-2) は日本クレア湖より購入した。 ビタミン・フリー・カゼインは ICN Biomedicals, Inc., Cleveland より，ミネラル混合 (AIN-76), およびビタ ミン混合（AIN-76）はオリエンタル酵母㑣より㲘入し た。p-nitrocatechol sulfate は Sigma 社より購入した。 全 RNA および mRNA 調製用試薬である ISOGEN 試 薬は橵)ニッポンジーンより購入した。試薬はすべて特級 のものを用いた。

\section{2. ラットの飼育条件}

離乳直後のウイスター系雄性ラットを $10 \%$ SPI 飼料, $10 \%$ カゼイン飼料，または固形飼料で 3 週間，あるいは 5 週間自由摂取させて飼育した。10\% SPI 飼料および $10 \%$ カゼイン飼料の組成は Table 1 に示した。朝 7 時 から夜 7 時を明時間とし明暗のサイクルは 12 時間とし て，20 22 ${ }^{\circ} \mathrm{C}$ の条件で管理し個別のケージで飼育した。 ラットはエーテル麻醉して屠殺した。午前 9 12 時の間 に実験を行った。

\section{3. 酲素活性の測定}

肝重量の 10 倍量の $0.25 \mathrm{M}$ スクロースでホモゲナイ ズし、そのホモジネートを醉素夜として用い,リンソーム アリルスルファターゼ活性およびリソッームフリルフミ ダーゼ活性を測定した。リソソームフリルスルファター セ活性は $p$-nitorocatechol sulfate を基質として, A とBのコンバインドフッセイ7)，またはB 単独活性 ${ }^{7}$ を 測定した。リソンームフリルアミダーゼ活性 ${ }^{8)}$ の測定は
Little らの方法9) で測定した。すなわち, $1.25 \mathrm{ml} の$ $0.1 \mathrm{M}$ トリス塩酸緩衝液 ( $\mathrm{pH} 7.4), 0.15 \mathrm{ml}$ の $10 \mathrm{mM}$ EDTA，および $0.1 \mathrm{ml}$ の酵素液を加兄， $37^{\circ} \mathrm{C} て ゙ 10$ 分 間予備加温した後, $15 \mu 1$ の $75 \mathrm{mM}$ ハシリン $\beta$-ナフチル アミドを基質として加反応を開始し 10 分間インキュ ベートした。遊離する $\beta$-ナフチルアミンはフゾ色素に して Goldbarg と Rutenburg の方法10)を用いて測定し た。醅素活性は 1 分間に $1 \mu \mathrm{mol}$ の $\beta$-ナフチルフミン, または p-nitrocatechol を遊離する醉素量を 1 unit と しだ。

\section{4. 全 RNA およびメッセンジャーRNA（mRNA） の調製}

各種飼料で 5 週間飼育したラット肝臓から McDonald ら11) の方法により全 RNAを調製した。全 RNA はオ リゴ $\mathrm{dT}$ セルロースカラムを用いてポリ $(\mathrm{A})+\mathrm{RNA}$ を 分画し mRNA 画分とした。

\section{5. ハイブリダイゼーションプローブの合成}

本実験で用いたハイブリダイゼーションプローブはヒ 卜，微生物，およびゥニのアリルスルファターゼの間で 保存されている領域について，+364-+381 の塩基配列 を選択し 1213)， 5'-C C C A A G G T G C C A C T T GC C-3'のオリコママーを Applied Biosystems 社の Model 392 DNA Synthesizer を用いて合成した。得られたオ

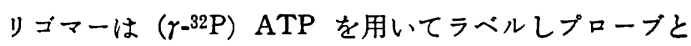
して供試した。

\section{6. ノーザンブロットおよびスロットブロット}

ノーザンプロットおよびスロットブロットは常法どお

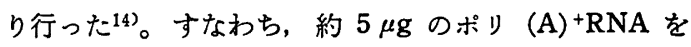
$1.0 \%$ アガロースゲルにアプライし $70 \mathrm{~V}$ で3時間電気 泳動した。さらにニトロセルロース膜にトランスファー した後, 先に述べたオリゴマープローブを用いて $37^{\circ} \mathrm{C}$ で 2 時間ハイブリダイゼーションを行った。フィルター を $6 \mathrm{XSSC}, 0.05 \% \mathrm{SDS}$ に打いて $47^{\circ} \mathrm{C}$ で 1 回洗浄し

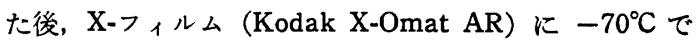
22 時間感光させた。また，スロットブロットは LKB Ultrascan XL Enhancer Leaser Densitometer を用い てスキャンしおおおののスロットを定量した。

\section{7. タンパク侗の定量}

タンパク質の定量はローリー法15)で牛血清アルブミン を標準として測定した。

\section{実 験 結 果}

\section{1. カセ゚インおよび分睢大豆タンパク篮 (SPI) 飼料 の配合組成およびアミノ酸組成}

$10 \%$ ガイン飼料（カゼイン飼料）および $10 \%$ 分離 大豆タンパク質飼料 (SPI 飼料) の配合組成を Table 1 に示した。アミノ酸組成をSPI 飼料とカゼイン飼料で比 
Table 2. Food intake, body weight, liver weight, and activities of lysosomal arylsulfatase (A \& B) and arylamidase in rats fed on semipurified diets for 5 weeks.

\begin{tabular}{lccccc}
\hline Diet & $\begin{array}{c}\text { Body } \\
\text { weight } \\
(\mathrm{g})\end{array}$ & $\begin{array}{c}\text { Liver } \\
\text { weight } \\
(\mathrm{g})\end{array}$ & $\begin{array}{c}\text { Food } \\
\text { intake } \\
(\mathrm{g})\end{array}$ & $\begin{array}{c}\text { Arylsulfatase } \\
\text { activity (A \& B) } \\
(\mathrm{mU} / \mathrm{mg} \text { protein) }\end{array}$ & $\begin{array}{c}\text { Lysosomal } \\
\text { arylamidase activity } \\
(\mathrm{mU} / \mathrm{mg} \text { protein) }\end{array}$ \\
\hline SPI & $94.6 \pm 1.5$ & $4.6 \pm 0.3$ & $306.6 \pm 34.1$ & $87.8 \pm 10.0^{\mathrm{a}}$ & $13.4 \pm 3.4$ \\
Casein & $132.7 \pm 9.0$ & $5.4 \pm 0.4$ & $349.0 \pm 23.2$ & $49.7 \pm 5.4^{\mathrm{b}}$ & $14.3 \pm 1.3$ \\
Laboratory chow & $390.6 \pm 13.1$ & $17.5 \pm 0.6$ & $706.6 \pm 45.0$ & $31.3 \pm 4.1^{\mathrm{c}}$ & $21.4 \pm 4.6$ \\
\hline \hline
\end{tabular}

Values are means $\pm \mathrm{SD} ; n=4$ rats/group. Values not sharing the same superscript letter within a column are significantly different when tested by ANOVA and Duncan's multiple-range test $(p<0.05)$.

較すると, Taniguchi と Cherian ${ }^{6)}$ の報告があるが, SPI 飼料中のメチオニンは約 $0.14 \%$ の割合で含まれカ ゼイン飼料の約半分であるが，シスチンは約 $0.13 \%$ の 割合で含まれたカゼイン飼料の約 2 倍含まれており，含 硫フミノ酸の粉量としてはSPI 飼料はカゼイン飼料の約 $75 \%$ である。また, SPI 飼料中のトリプトファンとプロ リンの含量はカゼイン飼料の約 $50 \%$, アルギニンおよび アスパラギン含量は約 2 倍である。その他のアミノ酸は ほほ同量含まれていた。

\section{SPI 飼料飼育によるアリルスルファターゼ活性の}

\section{上昇}

離乳直後のラットを固形飼料, カゼイン飼料, あるい はSPI 飼料で 5 週間飼育したときの体重および肝臓のリ ソソームアリルスルファターゼ活性（AとBコンパイン ド活性）の測定の結果を Table 2 に示した。おのおのの 飼料で飼育したラットの体重は固形飼料群に比較する と, カゼイン飼料群で約 $33 \%$, SPI 飼料群では約 $25 \%$ でありともに低タンパク質の影響がみられた。一方， リルスルファターゼ活性は固形飼料群に比べると体重で 減少していたのとは逆にカゼイン飼料群で約 1.6 倍（A と B コンハインド活性), SPI 飼料群では約 2.8 倍（A と Bコンハインド活性）にそれぞれ增加していた。一 方, 対照実験としてリッッームアリルアミダーゼ活性を 測定した (Table 2)。アリルアミダ一ゼ活性については, 固形飼料群に比べると逆にカゼイン飼料群, SPI 飼料群 ともに減少傾向を示した。このようにアリルスルファ ターゼ活性（AとBコンハインド活性）は固形飼料群に 比べると, カゼイン飼料群よりも含硫了ミノ酸の少ない SPI 飼料群でより高い活珄を示すことから, 肝蔵のリン ソームに局在するアリルスルファターゼは硫酸塩の代謝 に関与しており, 肝臓内での硫酸塩の濃度が活性の変動 に影槞を及ぼするのと思われる。そこで次に SPI 飼料で 飼育したラット肝葴のアリルスルファタ一ゼ活性に及ぼ すメチオニンおよびシスチン供給の効果を検討した。さ らにフリルスルファターゼはAとBが存在し7, 量的に はラット肝臓内ではAか～ $5 \%$ 弱, Bが $95 \%$ 強を占め
$ろ^{16)}$ ので活性上昇によりその量比に変化があるかどうか を調べた。

3. SPI 飼料で飼育したラット肝荟のアリルスルファ ターゼ活性に及ぼす含硫アミノ酸の効果

SPI $100 \mathrm{~g}$ 当りメチオニン，またはシスチンをそれ ぞれ $0.3 \mathrm{~g}$ 加えて, 離乳直後のラットを 3 週間飼育し肝 アリルスルファターゼ活性の A と B のコンパインド活 性またB単独の活性について検討した（Table 3)。こ の添加の割合は $10 \%$ カゼイン飼料の総含硫アミノ酸量 と同じになる割合である。 3 週間飼有後のラットの体重 は固形飼料群に比べ，カゼイン飼料群で約 $45 \%$, SPI 飼 料群では約 $35 \%$ であり低タンパク質の影響がみられた。 一方, アリルスルファターゼ活性については，AとBの コンパインド活性, および B 単独の活性ともに同程度上 昇し， B 活性の量比は 95\% 以上を占めた。つまり，ア リルスルファターゼ活性は, カゼイン飼料群と固形飼料 群の間では有意差はなかったが, SPI 飼料群ではAとB コンバインド活性が固形飼料群の約 1.9 倍, B 活性は約 2.3 倍に上昇していた。カゼイン飼料で 5 週間飼育した ラットでは肝フリルスルファターゼ活性は約 1.6 倍（A と Bコンハインド活性）に増加していたにもかかわらず 3 週間飼育では活性の上昇は観察されなかった。このこ とは, SPI 飼料群におけるフリルスルファターゼ活性の 上昇とカゼイン飼料群における上昇の機構が異なってい ることを示唆していて，低タンパク質飼料に加え低含硫 アミノ酸によるアリルスルファターゼ活性の上昇はより 短期間の内に起こると思われる。さらに, SPI 飼料にシ スチンまたは人チオニンを加えるとフリルスルファター ゼ活性（AとBコンバインド活性, および B活性）は, ィチオニンの抑制効果は劣るけれど、シスチンはカゼイ ン飼料打よび固形飼料群に㧊ける活性と同じレベルにま で抑制された。このことから，SPI 飼料によるアリルス ルファタービ活性の上昇は低含硫了ミノ酸組成による硫 酸塩の濃度の低下に起因することが確かめられた。一 方，対照実験としてリソソームアリルアミダーゼ活性を 测定した (Table 3)。アリルアミダーゼ活性について 
Table 3. Food intake, body weight, liver weight, and activities of lysosomal arylsulfatase and arylamidase in rats fed on semipurified diets for 3 weeks.

\begin{tabular}{|c|c|c|c|c|c|c|}
\hline \multirow{2}{*}{ Diet } & \multirow{2}{*}{$\begin{array}{l}\text { Body } \\
\text { weight } \\
\text { (g) }\end{array}$} & \multirow{2}{*}{$\begin{array}{l}\text { Liver } \\
\text { weight } \\
\text { (g) }\end{array}$} & \multirow{2}{*}{$\begin{array}{l}\text { Food } \\
\text { intake } \\
(\mathrm{g})\end{array}$} & \multicolumn{2}{|c|}{$\begin{array}{l}\text { Arylsulfatase activity } \\
\text { (mU/mg protein) }\end{array}$} & \multirow{2}{*}{$\begin{array}{c}\text { Lysosomal } \\
\text { arylamidase } \\
\text { activity } \\
\text { (mU/mg } \\
\text { protein) }\end{array}$} \\
\hline & & & & $(A \& B)$ & $\mathrm{B}$ & \\
\hline SPI $(n=8)$ & $100.0 \pm 3.5$ & $3.4 \pm 0.3$ & $231.9 \pm 18.9$ & $63.7 \pm 3.8^{\mathrm{a}}$ & $73.2 \pm 13.9^{a}$ & $17.6 \pm 3.9$ \\
\hline SPI (Met) $(n=8)$ & 146. $3 \pm 15.0$ & $5.5 \pm 0.8$ & $296.4 \pm 13.4$ & $44.2 \pm 6.5^{b}$ & $46.6 \pm 4.5^{b}$ & ND \\
\hline SPI (Cys) $(n=8)$ & $88.9 \pm 14.9$ & $3.6 \pm 0.6$ & $162.1 \pm 15.0$ & $33.0 \pm 2.7^{c}$ & $34.6 \pm 2.3^{c}$ & ND \\
\hline Casein $(n=8)$ & $123.3 \pm 9.2$ & $4.5 \pm 0.5$ & $242.3 \pm 37.7$ & $37.4 \pm 6.2^{c}$ & $32.6 \pm 10.6^{c}$ & $18.3 \pm 1.9$ \\
\hline $\begin{array}{l}\text { Laboratory } \\
\text { chow }(n=4)\end{array}$ & $222.6 \pm 6.2$ & $11.2 \pm 0.5$ & $361.0 \pm 30.7$ & $32.8 \pm 3.7^{\mathrm{c}}$ & $32.0 \pm 4.8^{\mathrm{c}}$ & $21.5 \pm 0.5$ \\
\hline
\end{tabular}

Values are means $\pm \mathrm{SD}$. Values not sharing the same superscript letter within a column are significantly different when tested by ANOVA and Duncan's multiple-range test (a/b,a/c $p<0.01, b / c p<0.05)$. ND, not determined. Cys, cystine.

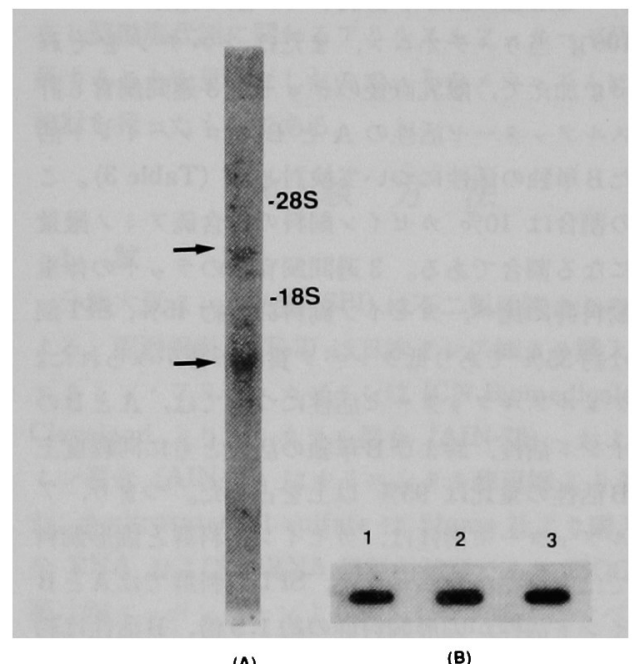

(A)

(B)

Fig. 1. (A) Northern blot analysis of liver arylsulfatase (AS) mRNA from rats fed on $10 \%$ SPI diet for 5 weeks.

Five $\mu \mathrm{g}$ of poly (A) + RNA was electrophoresed on a $1.0 \%$ formaldehyde-agarose gel, blotted to nitrocellulose membrane and hybridized to the arylsulfatase oligomer probe. Exporsure time was $22 \mathrm{~h}$ at $-70^{\circ} \mathrm{C}$. Arrows indicate arylsulfatase mRNAs : the upper, $3.5 \mathrm{~kb}$; the lower, $0.8 \mathrm{~kb}$.

(B) Slot-blot analysis of liver arylsulfatase mRNA.

Total RNA was isolated from livers of rats fed on laboratory chow (1), $10 \%$ casein diet (2), and 10 $\%$ SPI diet (3) for $\mathbf{5}$ weeks after weanling. Fifty $\mu \mathrm{g}$ of total RNA was applied with a manifold onto nitrocellulose membrane, hybridized to liver arylsulfatase oligomer probe, and autoradiographed.

は, 固形飼料群に比べると逆にカゼイン飼料群, SPI 飼 料群ともに減少傾向を示し 5 週間飼育実験と同じ結果を
Table 4. Effect of dietary casein and soybean protein isolate (SPI) on relative amounts of arylsulfatase (AS) mRNA in rat liver.

\begin{tabular}{|c|c|c|c|}
\hline \multirow[b]{2}{*}{ Diet } & \multicolumn{2}{|c|}{ Arylsulfatase } & \multirow{2}{*}{$\begin{array}{c}\text { Relative } \\
\text { amounts } \\
\text { of AS } \\
\text { mRNA }\end{array}$} \\
\hline & $\begin{array}{c}\text { Activity } \\
\text { (mU/mg } \\
\text { protein) }\end{array}$ & $\begin{array}{l}\text { Relative } \\
\text { activity }\end{array}$ & \\
\hline Laboratory & 31.3 & 1.0 & $1.0(n=2)$ \\
\hline Casein & 49.7 & 1.5 & $1.2(n=2)$ \\
\hline SPI & 87.8 & 2.8 & $1.1(n=2)$ \\
\hline
\end{tabular}

得た。

4. ノーザンブロットおよびスロットブロットによる アリルスルファターゼ mRNA の定量

カゼイン飼料扰よび SPI 飼料によるアリルスルフ ターゼの酵素活性上昇の機構を詳細に検討寸るためにア リルスルファターゼ mRNAのノーザンプロットを行っ た。種間で保存されたアミノ酸配列を選択して，オリゴ マーを合成し，( $\gamma$-32P) ATP でラベルしてプローブとし た。Fig.1A に示したよらに、アリルスルファターゼ mRNA は $0.8 \mathrm{~kb}$ と $3.5 \mathrm{~kb}$ の二の位置に観察され た。各飼料で 5 週間飼育したラット肝葴より調製した $50 \mu \mathrm{g}$ の全 RNA を用いてスロットブロットを行いアリ ルスルファターゼ mRNAの定量をした（Fig.1B）。 Table 4 にその結果を酵素活性と比較して示した。固形 飼料群の mRNA 量を 1.0 とした場合, カゼイン飼料 群で 1.2 倍, SPI 飼料群で 1.1 倍となり, 酵素活性の増 加と一致しないことがわかった。すなわちカゼインおよ び SPI 飼料によるアリルスルファターゼ活性の上昇は mRNA の合成増加を伴わないことを示すむのである。 


\section{考察}

SPI は低含硫了ミノ酸組成をむつタンパク質で，必須 アミノ酸含量 $(\mathrm{g} / 16 \mathrm{gN})^{6)}$ は次のとおりである。括弧内 に対照としてカゼインのものをあげた。メチオニン 1.4 (2.9), シスチン $1.3(0.65)$, バリン 5.1 (6.3), ロイ シン 8.0 (9.1), イソロイシン 5.1 (5.2), リジン 6.5 (7.9), スレオニン 3.8 (4.1), トリプトファン 1.4 (2.5), フェニルアラニン 5.3 (4.7), ヒスチジン 2.6 (2.3), およびフルギニン 8.1 (3.7) となり, SPI の含 硫了ミノ酸の総量はカゼインの $75 \%$ である。

このような低含硫了ミノ酸組成をもつSPI 飼料で離乳 直後のラットを数週間飼育すると, リソッームに局在し 硫酸塩の代謝に関わるアリルスルファターゼ活性が上昇 することを見いだした。この酵素はリソッーム内に $\mathrm{A}$ $\mathrm{B} か ゙$ 存在し, その相違は, 等電点が異なり $\mathrm{A} は 3.4, \mathrm{~B}$ は8.3であり, またAは䤃素反応速度論的に異常を示 し， B 単独の測定は可能であるが， A 活性測定時にはB 活性が重なってくるので両者を別々に測定するのは不可 能である7)。量的にはラット肝臓内ではAが $5 \%$ 弱, B が $95 \%$ 強を占める ${ }^{17)}$ 。このために低含硫了ミノ酸組成 のSPI 飼料で 3 週間飼育したラット肝缄で A と B のコン ハインント活性と, $\mathrm{B}$ 単独の活性を測定してみると, 固形

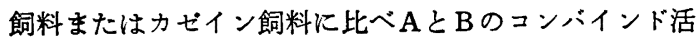
性と, B 単独の活性ともに同しょうに增加しその量比は $\mathrm{B}$ 活性が $95 \%$ 強を占めた。この活性の上昇はカゼイン 飼料で 5 週間飼育しても約 1.6 倍（AとBコンバインド 活性）に上昇し, SPI 飼料の 5 週間飼有でより顕著にな り両飼料による活性上昇の機棈に違いがみ!られるが, SPI 飼料にシスチンあるいはメチオニンを加えると 3 週 間飼育で活性の上昇が押えられることより，本醭素が細 胞内での硫酸塩の代謝に関与し, その濃度により変動す ることが示㖫される。

それでは，その変動のメカニズムとしてはどらなって いるのだろう。

低タンパク質飼料であるカゼイン飼料で 3 週間飼育し た場合, アリルスルファターゼ活性は固形飼料と同じレ ベルで活性の上昇はみられないか，5週間で約 1.6 倍 （AとBコンバインド活性）になった。発育期には数週 間低タンパク質飼育を行うと, 含硫了ミノ酸が第一制限 アミノ酸となり，これから代謝される硫酸塩の不足が顕 著になりこれを効果的に補らために，アリルスルファ ターゼ活性が代償的に上昇したと推定される。

SPI 飼料はカゼイン飼料に比ヘメチオニンが $50 \%$ 弱 と低く, シスチンは約 2.0倍と多いが, 全体でなお, 含 硫了ミノ酸は約 $75 \%$ の充足率である。SPI 飼料飼育に よりシステインの眝蔵タンパク質であるメタロチオネイ
ンおよびトリペプチドであるクルタチオンもともに著し 〈減少( ${ }^{536)}$, 硫酸塩の不足が顕著になっていることを 示唆する。これらのことと肝蔵システイン量は生後 3 週

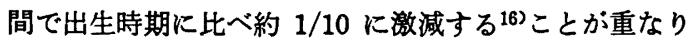
あらことが重要な活性上昇因子になり、アリルスルファ ターゼ活性の上昇が誘発されると思われる。これは SPI 飼料にシスチンを添加するとフリルスルファターセ活性 の上昇が抑壳られることからも推測される。この場合, 添加されたシスチンはタンパク質合成に回される以上に 十分存在し、システインから硫酸塩の供給が十分に賄わ れるためと思われる。このときシスチン添加群は，餌の 摂取量が SPI 群の $70 \%$ に落ち込むが，タンパク質効率 (PER) の値は SPI のものと同じで約 2.2 となる。こ のためアリルスルファターゼ活性の低下はシスチン添加 SPI 飼料の摂取量の低下に起因する可能性は少ないと考 えられる。

低タンパク質飼育時は，ホモシステインからメチオニ ンへの合成型へ，またグルタチオンが分解型に傾きシス テインへの合成型へと代謝が進む。10\% SPI 飼料は低 タンパク質でさらにメチオニン含量が少ないのでこのア ミノ酸のシステインへの供給は少なく、硫酸塩への寄与 率はさらに少なくなると考えられる。一方, システイン はグルタチオンから補給されるが, システインは生後 3 週間で肝贜から激減しさらに, 総含硫了ミノ酸はカゼイ ขの $75 \%$ と低いので, 細胞内硫酸塩濃度の上昇への寄 与率も少ないと考えられる。

メチオニンからシスティンへの代謝の律速段階の醳素 の一つであるシスタチオナーゼ活性は, ラット肝蔵では 生後 4 週間で成熟ラットのレベルに達する ${ }^{(6)}$ か，低タン パク質飼育時はこの活性は著しく低下する。このため SPI 飼料へのメチオニンとシスチンの添加効果の差はこ の醭素活性の变動に起因するとは考光にくい。

メチオニンの添加は, このアミノ酸が低タンパク質飼 料による長期の飼育のため第一制限フミノ酸となってい るので，タンパク質合成により多く使われ，シスチンの 添加ほど細胞内の硫酸塩の增加に至らず， アリルスル ファターゼ活性の上昇の抑制がシスチン添加よりも劣る あのと思われる。

両フミノ酸の添加効果，つまり本酵素活性に影響する のは, シスチンまたはメチオニンにかかわらず, 細胞内 総硫酸塩濃度たと考兄られる。これは(1)シスチン添加で もメチオニン添加でもフリルスルファターゼ活性は低下 すること，(2)SPI 飼料とカゼイン飼料のアミノ酸組成の 比較からシスチンの割合たけが高くても, 総含硫了ミ， 酸の含量が低いと本醉素活性が低下すること，この 2 点 から理解できる。メチオニン添加もシスチン添加もどち らも硫酸塩の補給には差はないと考光られる。しかし, 
量的な問題としてィチオニン添加の場合は,タンパク質 効率が増し細胞内総硫酸塩濃度の増加に対する寄与率 は，シスチン添加よりも少ないと考えられる。

含硫アミノ酸の少ないSPI 飼料で離乳期より数週間 ラットを飼育すると, 肝臓グルタチオンが対照のレベル の $20 \%$ に減少する一方，この代謝酵素である肝臓 GGT 活性が約 5 倍に增加することが報告されている5゙がこの 上昇の詳しいメカニズムはいまだわかっていない。一 方, SPI 飼料による脂肪酸合成系の䤃素活性の減少が報 告されているが， mRNA の量に変化を与えず，翻訳の 過程の減少として報告されている4)。SPI 飼料による本 アリルスルファターセ活性の上昇はドットブロット法で mRNA の合成増加を伴わないことが示された。つまり フリルスルファターゼ活性の上昇の機構は酔素の活性 化，または阻害剤の有無による可逆的調節，さらに翻訳 の過程によるタンパク質合成量の增加か, 分解量の減少 か，または，両者のバランスによる。一般にアリルスル ファターゼ活性はリン酸イオンと硫酸イオンに強く阻害 される ${ }^{18)}$ 。含硫了ミ/酸の添加により肝蔵内の硫酸塩濃 度が上昇して活性が抑えられる可能性も考えられること から，予備実験として各サンプルを透析してその活性を 測定したが，活性が変わることはなかった。このことか ら低分子による直接の酵素の活性化，または阻害はない と考えられる。対照実験として測定したリソッームアリ ルアミダーゼ活性は各飼料群間で差はなくむしろ減少し た。このことからリンンーム自身の分解の遅れによるア リルスルファターゼ活性の上昇の可能性は否定される。 これらの事実から、アリルスルファターゼ活性の上昇の 機構は, 硫酸塩の不足がシグナルとなり何らかの形で mRNA の翻訳の過程の增加によるタンパク質合成量の 增加を伴うことが示唆される。

細胞内での硫酸塩の重要さはウ二胚の発生の泼胞期以 降は硫酸イオンが不可欠であることからもわかる199。本 実験からも推測されるがその不足は種々の硫酸塩の代謝 に関する醅素の変動を引き起こす。低含硫了ミノ酸組成 をむつSPI 飼料によるリソソームアリルスルファターゼ 活性の上昇の生理的意味としては，発育期の動物に顕著 に現れる硫酸塩の不足を効果的に補うための代償作用と 思われる。フリルスルファターゼの生理的な役割として 種々の報告があり 20) 22)，生理的な変動ではエイジング に関する報告があるが23)，本実験により栄養条件の差に よるフリルスルファターゼ活性の変動が確認された。

$$
\text { 要 約 }
$$

離乳直後のウイスター系雄性ラットを固形飼料，10\% カゼイン飼料，あるいは $10 \%$ SPI 飼料で 5 週間飼育し て, 低含硫アミノ酸飼料の肝蔵アリルスルファターセ活
性に及ぼす影響について調べた。

1) AとBのコシパインド活性でみると, 固形飼料群 は 3，5週間ともに約 $32 \mathrm{mU} / \mathrm{mg}$ protein で差がなく， カゼイン飼料群では 3 週間飼育のものは固形飼料群と差 がないか， 5 週間 飼 育すると，活性は約 $50 \mathrm{mU} / \mathrm{mg}$ protein となり固形飼料群のものより約 1.6 倍に上昇し た。一方, SPI 飼料群のものは, 3 週間で約 $64 \mathrm{mU} / \mathrm{mg}$ protein となり固形飼料群の約 1.9 倍, 5 週間で約 88 $\mathrm{mU} / \mathrm{mg}$ protein となり約 2.8 倍に活性が上昇した。フ リルスルファターゼB活性についても同じ增加の結果を 得た。この活性上昇はシスチンまたはメチオニンの SPI 飼料への添加で抑制された。

一方, 同じリッンーム内酵素であるアリルアミダーゼ 活性は 3 週間, おょび 5 週間飼育では固形飼料群に比 べ,カゼイン飼料群およびSPI 飼料群の活性は低下した。

2）ノーザンブロットおよびスロットブロットの結 果, 5 週間飼育ラット肝臓から得られた固形飼料群の mRNA の量は, これを 1 とすると，カゼイン飼料群で 約 1.2 倍, SPI 飼料群で約 1.1 倍となり差はなかった。

\section{文献}

1）菅野道廣：栄食誌，40，93（1987）

2) 山本孝史, 井上五郎 : 栄食誌, 44, 155 (1991)

3) Shinjo, S., Asato, L., Arakaki, S., Kina, T., Kohrin, T., Mori, M. and Yamamoto, S. : J. Nutr. Sci. Vitaminol., 38, 247 (1992)

4) Iritani, N., Nagashima, K., Fukuda, H., Katsurada, A. and Tanaka, T. : J. Nutr., 116, 190 (1986)

5) Taniguchi, M. and Inoue, M. : J. Biochem., 100,1457 (1986)

6) Taniguchi, M. and Cherian, M.G. : Br. J. Nutr., 63, 97 (1990)

7) Worwood, M., Dodgson, K.S., Hook, G.E.R. and Rose, F.A. : Biochem. J., 134, 183 (1973)

8) Mahadevan, S. and Tappel, A.L. : J. Biol. Chem., 242, 2369 (1967)

9) Little, G.H., Starnes, W.L. and Behal, F.J. : Methods Enzymol., 45, 495 (1976)

10) Goldbarg, J.A. and Rutenburg, A.M. : Cancer, 11, 283 (1958)

11) McDonald, R.J., Swift, G.H., Przybyla, A.E. and Chirgwin, J.M. : Methods Enzymol., 152, 224 (1987)

12) Sasaki, H., Yamada, K., Akasaka, K., Kawasaki, H., Suzuku, K., Saito, A., Sato, M. and Shimada, H.: Eur. J. Biochem., 177, 9 (1988)

13) Yamada, K., Akasaka, K. and Shimada, H. : Eur. J. Biochem., 186, 405 (1989)

14) Sambrook, D., Fritsch, E. and Maniatis, T.: Molecular Cloning: A Laboratory Mannual (1989), Cold Spring Harbor Lab. (Cold Spring Harbor)

15) Lowry, O.H., Rosebrough, N.J., Farr, A.L. and Ranball, R.J.: J. Biol. Chem., 193, 265 (1951)

16）安房田司郎，中山和子，三笠洋明，览玉裕敬：含 
硫厂ミノ酸, 7, 407 (1984)

17) Hook, G.E.R., Dodgson, K.S., Rose, F.A. and Worwood, M.: Biochem. J., 134, 191 (1973)

18) Carlson, R.W., Downwing, M. and Tolbert, B.M. : Biochemistry, 16, 5221 (1977)

19）赤坂甲治, 山田一美, 嶋田 拓：生化学, 64, 485 (1992)

20) Thompson, D.B. and Daniel, W.L. : Enzyme, 37, 134 (1987)
21) Mumma, R.O. and Verlangieri, A.J. : Biochim. Biophys. Acta, 273, 249 (1972)

22) Uchida, T., Egami, F. and Roy, A.B. : Biochim. Biophys. Acta, 657, 356 (1981)

23) Ferland, G., Perea, A., Audet, M. and Tuchweber, B. : Mech. Aging Dev., 56, 143 (1990)

(1993 年 1 月 22 日受理) 